\title{
A MATHEMATICAL MODEL OF NOISE IN THE MEASURING CHANNELS OF INTELLIGENT SYSTEMS
}

\author{
G.I. Volovich, South Ural State University, Chelyabinsk, Russian Federation, \\ g_volovich@mail.ru, \\ E.V. Solomin, South Ural State University, Chelyabinsk, Russian Federation, \\ nii uralmet@mail.ru,
}

I.G. Topolskaya, South Ural State University, Chelyabinsk, Russian Federation, irina_topol71@mail.ru,

D. $\overline{\text {. }}$. Topolsky, South Ural State University, Chelyabinsk, Russian Federation, topol69@mail.ru

\begin{abstract}
We propose a mathematical model describing quantization frequency selection in the measuring channels of intelligent systems depending on the parameters of noise. We consider internal and external sources of noise, seek the reasons for noise generation, justify the necessity of recording noise in the analog lines of measuring channels of intelligent systems. The parameters of our mathematical model of noise are: stationary white noise with normal distribution, an anti-aliasing bandwidth filter, the variance of noise at the input of an analog-digital converter, the correlation coefficient of noise. We evaluate the dependence of the selection of quantization frequency value on the parameters of noise. We show that if the right sampling frequency is selected in the conditions of broadband noise measuring then the systematic component of error is determined by the bandwidth of the low frequency analog anti-aliasing filter, while the random error is determined by the bandwidth of the low frequency digital averaging filter.
\end{abstract}

Keywords: mathematical model; noise; intelligent systems; quantization frequency.

\section{Introduction}

Measuring the parameters of signals in measuring channels of intellectual systems simultaneously with the main signal, we have registered the interfering signals - noises and interferences of different nature. The sources of noises are both internal and external. The internal noises may physically attend signal sources similar to the heat noise of electron flows in electric circuits and shot effects in electronic devices or may appear in measuring apparatus and systems of data transmission and processing due to different destabilizing factors - temperature, higher humidity, instability of power sources, mechanical vibrations on galvanic contacts, etc. External noise sources can be of natural and artificial kind. Among the artificial industrial interference sources are the engines, switchers, generators of different signal forms, etc. Natural sources of interferences are lightning, magnetic field fluctuations, solar energy flashes, etc [1]. All these factors should be counted in intellectual system measuring channels development. The most visible is the effect of noise of the analog circuits of measuring channels. The pickup of useful components from the overall sum of registered signals or maximum noise and interference suppression in information signal saving its useful components, is one of the main development tasks. Therefore we evaluate the dependence of quantization frequency value selection on the noise parameters and propose the approach of construction of the mathematical model of noise in intellectual system measuring channels. 


\section{Mathematical Model of Noise}

Let us evaluate the effect of noise parameters on quantization frequency selection [2, 3]. The signal on the input of measuring device is given by

$$
u(t)=U_{m} \cos \left(\omega_{1} t+\phi\right)+\eta(t)
$$

where $\eta(t)$ is a stationary centered white noise with normal distribution and spectral density G. If the anti-aliasing filter with rectangular amplitude-frequency characteristic (AFC) is included into the signal normalizing circuit, then the correlation function of noise on the input of analog-digital converter (ADC) is given by

$$
K(\tau)=2 G^{2} \frac{\sin \omega_{\alpha} \tau}{\tau}=\sigma^{2} R(\tau)
$$

where $\omega_{\alpha}$ is an anti-aliasing filter bandwidth,

$$
\sigma=G \sqrt{2 \omega_{\alpha}}
$$

is a mean square noise deviation on ADC input [4] and $R(\tau)=\frac{\sin \omega_{\alpha} \tau}{\omega_{\alpha} \tau}$ is a coefficient of correlation of this noise.

We neglect the level of discrecity of quantization. Then after squaring the output data of ADC is given by

$$
\left\lceil u^{*}(t)\right\rceil^{2}=\left\lceil u(t) * T_{s} \sum_{k=-\infty}^{\infty} \delta\left(t-k T_{s}\right)\right\rceil^{2}=u^{2}(t) *\left\lceil T_{s} \sum_{k=-\infty}^{\infty} \delta\left(t-k T_{s}\right)\right\rceil^{2}
$$

where $T_{s}=1 / f_{s}$ is a period of sampling. Thereby we can formally rearrange the operations for squaring and sampling. In this case due to (1):

$$
u^{2}(t)=\left(U_{m}^{2} / 2\right)+\left(U_{m}^{2} / 2\right) \cos 2\left(\omega_{1} t+\phi\right)+2 \eta_{1}(t) U_{m} \cos \left(\omega_{1} t+\phi\right)+\eta_{1}(t)
$$

where $\eta_{1}(t)$ is the noise on ACD input. Mathematical expectation of signal (4)

$$
m_{u^{2}}=U_{m}^{2} / 2+\sigma^{2}
$$

hows the square of effective value of voltage on ACD input.

Product moment of the second degree of function (4) is given by

$$
m_{11}(\tau)=\left\lceil\left(U_{m}^{4} / 4\right) *\left(1+1 / 2 \cos 2 \omega_{1} \tau\right)\right\rceil+U_{m}^{2}\left\lceil 2 K(\tau) \cos \omega_{1} \tau+\sigma^{2}\right\rceil+\sigma^{4}+2 K^{2}(\tau) .
$$

From this equation we can find the correlation function of signal (4) [1]:

$$
K_{u^{2}}(\tau)=\left\lceil m_{11}(\tau)-m_{u^{2}}^{2}\right\rceil=\left(U_{m}^{4} / 8\right) \cos 2 \omega_{1} \tau+2 U_{m}^{2} K(\tau) \cos \omega_{1}+2 K^{2}(\tau) .
$$

For calculation of one-side spectral density we used Wiener-Khinchin theorem [5]:

$$
S_{u^{2}}(\omega)=4 \int_{0}^{\infty} K_{u^{2}}(\tau) \cos \omega \tau d \tau
$$


After substitution of correlation function (6) into (7) and taking into account (2) we find

$$
S_{u^{2}}(\omega)=\left(U_{m}^{4} / 8\right) \delta\left(\omega-2 \omega_{1}\right)+S_{1}(\omega)+S_{2}(\omega)
$$

and

$$
\begin{gathered}
S_{1}(\omega)= \begin{cases}\frac{4 \pi \sigma^{2} U_{m}^{2}}{\omega_{\alpha}}, & 0<\omega<\omega_{\alpha}-\omega_{1}, \\
\frac{2 \pi \sigma^{2} U_{m}^{2}}{\omega_{\alpha}}, & \omega_{\alpha}-\omega_{1}<\omega<\omega_{\alpha}+\omega_{1}, \\
0, & \omega>\omega_{\alpha}+\omega_{1},\end{cases} \\
S_{2}(\omega)= \begin{cases}\frac{2 \pi \sigma^{4}}{\omega_{\alpha}^{2}}\left(2 \omega_{\alpha}-\omega\right), & 0<\omega<2 \omega_{\alpha}, \\
0, & \omega>2 \omega_{\alpha} .\end{cases}
\end{gathered}
$$

Equation (8) shows that the spectrum $S_{u^{2}}(\omega)$ is discrete-solid. It consists of a discrete spectrum line $2 \omega_{1}$, caused by harmonic signal $U_{m} \cos \left(\omega_{1} t+\phi\right)$ and two big components in the input signal.

The ratio of maximal values $S_{1}(\omega)$ and $S_{2}(\omega)$

$$
\frac{S_{1}(0)}{S_{2}(0)}=\frac{U_{m}^{2}}{\sigma^{2}}
$$

therefore in accurate measurements $U_{m}>>\sigma$, we neglect the effect of component $S_{2}(\omega)$.

When we sampling the signal in time (4), we get the reflecting components of spectrum $S_{u^{2}}$, therefore the spectrum of a sampled signal in the scale of cyclic frequency $f$ [6]:

$$
S_{T}(f)=\sum_{n=-\infty}^{\infty} S_{u^{2}}\left(f-n f_{s}\right) .
$$

To make the effect of reflecting components $S_{T}(f)$ on measuring accuracy less, we should avoid their presence in the bandwidth of averaging digital low-pass filter (LPF) [7], but it is possible only when the following condition holds:

$$
f_{s}-\left(f_{a}+f_{1}\right)>f_{c} \text { или } f_{s}>f_{c}+f_{a}+f_{1} .
$$

If condition (3) is true, then the signal on the output of averaging LPF $\left\lceil u_{F}^{*}(i)\right\rceil^{2}$ has constant component which is equal to the mathematical expectation $u^{2}(t)(11)$ and noise component $\xi(t)$ :

$$
\left\lceil u_{F}^{*}(i)\right\rceil^{2}=U_{m}^{2}+\sigma^{2}+\xi\left(t_{i}\right)
$$

Let us find the dispersion of noise on the output of averaging LPF. Considering that $S_{2}(\omega)$ is small,

$$
D_{\xi}=\frac{1}{2 \pi} \int_{0}^{\infty} S_{f}(\omega) d \omega=\frac{1}{2 \pi} \int_{0}^{\omega_{c}} \frac{4 \pi \sigma^{2} U_{m}^{2}}{\omega_{\alpha}} d \omega=2 \sigma^{2} U_{m}^{2} \frac{\omega_{c}}{\omega_{a}}
$$

where $S_{F}(\omega)$ is the spectrum of noise on the output of averaging LPF. The output signal of digital voltmeter [8]:

$$
u_{O U T}^{*}(i)=\sqrt{\left\lceil u_{F}^{*}(i)\right\rceil^{2}} \approx \frac{U_{m}}{\sqrt{2}}\left[1+\frac{\sigma^{2}+\xi^{*}(i)}{U_{m}^{2}}\right] .
$$


And the relative error of measurement caused by noise:

$$
\frac{\Delta U}{U} \approx \frac{\sigma^{2}+\xi^{*}(i)}{U_{m}^{2}}
$$

Although the noise $\eta_{1}^{2}(t)$ has distribution other than normal, passing through the narrow band averaging LPF it will be "normalized" [5]. Therefore $\xi(t)$ has the distribution closed to normal and with probability of 0,986 the relative error of measurement:

$$
\frac{\Delta U}{U}<\frac{\sigma^{2}+3 \sqrt{D_{\xi}}}{U_{m}^{2}}=\frac{\sigma^{2}}{U_{m}^{2}}+\frac{4,24 \sigma}{U_{m}} \sqrt{\frac{f_{c}}{f_{a}}} .
$$

The first summand in formula (13) is the deterministic error component caused by noise, and the second is random. Substituting the value of $\sigma$ from (3) into (13), finally we get:

$$
\frac{\Delta U}{U}<\frac{4 \pi f_{a} G^{2}}{U_{m}^{2}}+\frac{15 G}{U_{m}} \sqrt{f_{c}}
$$

Let us show the example. Assume that the sampling frequency is $f_{s}=10 \mathrm{kHz}$, bandwidth of anti-aliasing filter is $f=4 \mathrm{kHz}$, bandwidth of averaging is $f_{c}=4,4 \mathrm{~Hz}$, frequency of signal $f_{1}<f$, effective value of measuring signal is $U=1 \mathrm{~V}$, mean square value of noise is with normal distribution and constant spectral density in the band width $0<f<f_{a}$ is $\sigma=0,01 \mathrm{~V}$. Then the condition (11) holds, the first summand in formula (13) is equal to $5 \cdot 10^{5}$, and the second is equal to $9,9 \cdot 10^{4}$, i. e. almost 20 times higher. Therefore in this example the main part of error is the random component. This allows us to conclude that in measuring of the wide bandwidth noise, when the sampling frequency is selected correctly, the systematic component of error is determined by the bandwidth of analog anti-aliasing LPF, and random - by the bandwidth of averaging digital LPF.

This work was supported by R.F. Ministry of Education under the Federal Program "Research and development on priority directions of scientific-technological complex of Russia for 2014-2020" by Grant 14.576.21.0047 om 22.08.2014.

\section{References}

1. Davydov A.V. Signaly i lineynye sistemy: Tematicheskie lektsii [Signals and Linear Systems: Thematic Lectures]. Yeakaterinburg, UGGU, IGG, 2005. 289 p. (in Russian)

2. Rathore T.S. Digital Measurement Techniques. Bristol, Alpha Science Int., 2003. 376 p.

3. V'yukhin V.N., Popov Y.A., Tani Y.L. [Research of Method of Coherent Sampling for Testing of High Charge ADC]. Avtometriya [Optoelectronics, Instrumentation and Data Processing], 1997, no. 5, pp. 9-14. (in Russian)

4. Bennett W.R. Spectra of Quantized Signals. Bell Systems Technical Journal, 1948, vol. 27, issue 3, pp. 446-472. DOI: 10.1002/j.1538-7305.1948.tb01340.x

5. Tihonov V.I. Statisticheskaya radiotekhnika [Statistic Radio Engineering]. Moscow, Radio i svyaz, 1982. 624 p.

6. Kuzin L.T. Raschet i proektirovanie diskretnykh sistem upravleniya [Calculation and Development of Discrete Control Systems]. Moscow, Mashgiz, 1962. 684 p. 
7. Analog-Digital Converting. Edited by W. Kester, Analog Devices, Inc. 2004. 1016 p.

8. Gubler G.B., Gutnikov V.S. [Algorythms of Digital Processing of Signals of MultiFunctional Etalon Device for Measuring the Electric Engineering Values]. Available at: http://www.mars-energo.ru/p/a/algorithms.pdf (accessed 6 September 2014)

Received September 6, 2014

УДК 51-74

DOI: $10.14529 / \mathrm{mmp} 140410$

\title{
МАТЕМАТИЧЕСКАЯ МОДЕЛЬ ШУМА \\ В ИЗМЕРИТЕЛЬНЫХ КАНАЛАХ ИНТЕЛЛЕКТУАЛЬНЫХ СИСТЕМ
}

\author{
Г.И. Волович, Е.В. Соломин, И.Г. Тополъская, Д.В. Топольский
}

\begin{abstract}
В данной статье предложена математическая модель, описывающая влияние параметров шума на выбор частоты дискретизации в измерительных каналах интеллектуальных систем. Были приведены внутренние и внешние источники шума, проанализированы причины возникновения шумов, обоснована необходимость учета влияния шума в аналоговых цепях измерительных каналов интеллектуальных систем. Параметрами математической модели шума являются стационарный центрированный белый шум с нормальным распределением, полоса пропускания антиалайзингового фильтра, среднеквадратичное отклонение шума на входе аналого-цифрового преобразователя, коэффициент корреляции этого шума. Проведена оценка влияния параметров шума на выбор частоты дискретизации. Она показала, что при измерении в условиях широкополосного шума, при правильном выборе частоты выборок, систематическая составляющая погрешности определяется полосой пропускания аналогового антиалайзингового фильтра низкой частоты, а случайная - полосой пропускания усредняющего цифрового фильтра низкой частоты.

Ключевые слова: математическал модель; иум; интеллектуальные системы; частота дискретизации.
\end{abstract}

\section{Литература}

1. Давыдов, А.В. Сигналы и линейные системы: тематические лекции / А.В. Давыдов. - Екатеринбург: УГГУ, ИГиГ, 2005. - 289 с.

2. Ратхор, Т.С. Цифровые измерения. Методы и схемотехника: пер. с англ. T.C. Ратхор. - M.: Техносфера, 2004. - 376 c.

3. Вьюхин, В.Н. Исследование метода когерентной выборки для тестирования высокоразрядных АЦП / В.Н. Вьюхин, Ю.А. Попов, Ю.Л. Тани // Автометрия. 1997. - № 5. - C. 9-14.

4. Bennett, W.R. Spectra of Quantized Signals / W.R. Bennett // Bell Systems Technical Journal. - 1948. - V. 27, issue 3. - P. 446-472.

5. Тихонов, В.И. Статистическая радиотехника / В.И. Тихонов. - М.: Радио и связь, 1982. -624 c.

6. Кузин, Л.Т. Расчет и проектирование дискретных систем управления / Л.Т. Кузин. - М.: Машгиз, 1962. - 684 с. 
7. Аналого-цифровое преобразование: пер. с англ. / под ред. У. Кестера. - М.: Техносфера, 2007. - 1016 c.

8. Гублер, Г.Б. Алгоритмы цифровой обработки сигналов многофункционального эталонного прибора для измерений электроэнергетических величин / Г.Б. Гублер, B.C. Гутников. - URL: http://www.mars-energo.ru/p/a/algorithms.pdf

Георгий Иосифович Волович, доктор технических наук, профессор, кафедра «Системы управления», Южно-Уральский государственный университет (г. Челябинск, Российская Федерация), g_volovich@mail.ru.

Евгений Викторович Соломин, доктор технических наук, профессор, кафедра «Өлектротехника и возобновляемые источники энергии», Южно-Уральский государственный университет (г. Челябинск, Российская Федерация), nii_uralmet@mail.ru.

Ирина Геннадьевна Топольская, ассистент, кафедра «Электротехника и возобновляемые источники энергии», Южно-Уральский государственный университет (г. Челябинск, Российская Федерация), irina_topol71@mail.ru.

Дмитрий Валерианович Топольский, кандидат технических наук, доцент, кафедра «Электротехника и возобновляемые источники энергии», Южно-Уральский государственный университет (г. Челябинск, Российская Федерация), topol69@mail.ru.

Поступила в редакцию 6 сентября 2014 г. 